\title{
Wolf Prize in Mathematics
}

Volume 1 
This page is intentionally left blank 


\title{
Wolf Prize in Mathematics
} Volume 1

\author{
Edited by \\ S S Chern \\ University of California, Berkeley, USA E \\ Mathematical Sciences Research Institute, USA \\ F Hirzebruch \\ Universität Bonn $\mathcal{E}$ \\ Max-Planck-Institut für Mathematik, Germany
}




\section{Published by}

World Scientific Publishing Co. Pte. Ltd.

P O Box 128, Farrer Road, Singapore 912805

USA office: Suite 1B, 1060 Main Street, River Edge, NJ 07661

UK office: 57 Shelton Street, Covent Garden, London WC2H 9HE

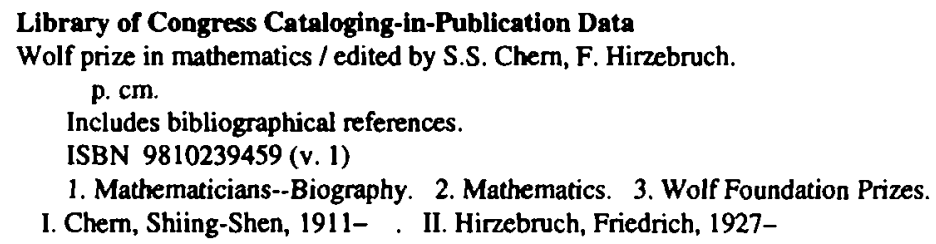

QA28.W65 2000

$510.92^{\prime} 2--\mathrm{dc} 21$

[B]

00-031994

British Library Cataloguing-in-Publication Data

A catalogue record for this book is available from the British Library.

The editors and publisher would like to thank the following organisations and publishers of the various journals and books for their assistance and permission to reproduce the selected reprints found in this volume:

Academic Press

Almqvist \& Wiksell

American Institute of Physics

American Mathematical Society

Gauthier-Villars

International Press

Israel Mathematical Society

The Johns Hopkins University Press

Mathematical Association of America

Mathematical Society of Japan

\author{
Nagoya University Press \\ National Academy of Sciences (USA) \\ Princeton University Press \\ The Royal Swedish Academy of Sciences \\ Société Mathématique de France \\ Springer-Verlag \\ University of Illinois Press \\ Vandenhoeck \& Ruprecht \\ The Wolf Foundation
}

While every effort has been made to contact the publishers of reprinted papers prior to publication, we have not been successful in some cases. Where we could not contact the publishers, we have acknowledged the source of the material. Proper credit will be accorded to these publishers in future editions of this work after permission is granted.

Copyright $\odot 2000$ by World Scientific Publishing Co. Pte. Ltd.

All rights reserved. This book, or parts thereof, may not be reproduced in any form or by any means, electronic or mechanical, including photocopying, recording or any information storage and retrieval system now known or to be invented, without written permission from the Publisher.

For photocopying of material in this volume, please pay a copying fee through the Copyright Clearance Center, Inc., 222 Rosewood Drive, Danvers, MA 01923, USA. In this case permission to photocopy is not required from the publisher. 


\begin{tabular}{|c|c|c|}
\hline 1978 & $\begin{array}{l}\text { Izrail M. Gelfand } \\
\text { Carl L. Siegel }\end{array}$ & $\begin{array}{l}1913 \\
1896-1981\end{array}$ \\
\hline 1979 & $\begin{array}{l}\text { Jean Leray } \\
\text { André Weil }\end{array}$ & $\begin{array}{l}1906-1998 \\
1906-1998\end{array}$ \\
\hline 1980 & $\begin{array}{l}\text { Henri Cartan } \\
\text { Andrei N. Kolmogorov }\end{array}$ & $\begin{array}{l}1904 \\
1903-1987\end{array}$ \\
\hline 1981 & $\begin{array}{l}\text { Lars V. Ahlfors } \\
\text { Oscar Zariski }\end{array}$ & $\begin{array}{l}1907-1996 \\
1899-1986\end{array}$ \\
\hline 1982 & $\begin{array}{l}\text { Hassler Whitney } \\
\text { Mark Grigor'evich Krein }\end{array}$ & $\begin{array}{l}1907-1989 \\
1907-1989\end{array}$ \\
\hline $1983 / 4$ & $\begin{array}{l}\text { Shiing-Shen Chern } \\
\text { Paul Erdös }\end{array}$ & $\begin{array}{l}1911 \\
1913-1996\end{array}$ \\
\hline $1984 / 5$ & $\begin{array}{l}\text { Kunihiko Kodaira } \\
\text { Hans Lewy }\end{array}$ & $\begin{array}{l}1915-1997 \\
1904-1988\end{array}$ \\
\hline 1986 & $\begin{array}{l}\text { Samuel Eilenberg } \\
\text { Atle Selberg }\end{array}$ & $\begin{array}{l}1913-1998 \\
1917\end{array}$ \\
\hline 1987 & $\begin{array}{l}\text { Kiyosi Itô } \\
\text { Peter D. Lax }\end{array}$ & $\begin{array}{l}1915 \\
1926\end{array}$ \\
\hline 1988 & $\begin{array}{l}\text { Friedrich Hirzebruch } \\
\text { Lars Hörmander }\end{array}$ & $\begin{array}{l}1927 \\
1931\end{array}$ \\
\hline 1989 & $\begin{array}{l}\text { Alberto P. Calderon } \\
\text { John W. Milnor }\end{array}$ & $\begin{array}{l}1920-1998 \\
1931\end{array}$ \\
\hline 1990 & $\begin{array}{l}\text { Ennio De Giorgi } \\
\text { Ilya Piatetski-Shapiro }\end{array}$ & $\begin{array}{l}1928-1996 \\
1929\end{array}$ \\
\hline 1992 & $\begin{array}{l}\text { Lennart A. E. Carleson } \\
\text { John G. Thompson }\end{array}$ & $\begin{array}{l}1928 \\
1932\end{array}$ \\
\hline 1993 & $\begin{array}{l}\text { Mikhael Gromov } \\
\text { Jacques Tits }\end{array}$ & $\begin{array}{l}1943 \\
1930\end{array}$ \\
\hline $1994 / 5$ & Jürgen K. Moser & $1928-1999$ \\
\hline $1995 / 6$ & $\begin{array}{l}\text { Robert Langlands } \\
\text { Andrew J. Wiles }\end{array}$ & $\begin{array}{l}1936 \\
1953\end{array}$ \\
\hline $1996 / 7$ & $\begin{array}{l}\text { Joseph B. Keller } \\
\text { Yakov G. Sinai }\end{array}$ & $\begin{array}{l}1923 \\
1935\end{array}$ \\
\hline 1999 & $\begin{array}{l}\text { László Lovász } \\
\text { Elias M. Stein }\end{array}$ & $\begin{array}{l}1948 \\
1931\end{array}$ \\
\hline 2000 & $\begin{array}{l}\text { Raoul Bott } \\
\text { Jean-Pierre Serre }\end{array}$ & $\begin{array}{l}1923 \\
1926\end{array}$ \\
\hline
\end{tabular}


This page is intentionally left blank 


\section{Preface}

There is no Nobel prize in mathematics. Perhaps this is a good thing. Nobel prizes create so much public attention that mathematicians would lose their concentration to work.

There are several other prizes for mathematicians. There is the Fields medal (only for mathematicians). This medal is awarded to mathematicians who are at most 40 in the year of the International Congress of Mathematicians where the medals are presented. Thus it honours outstanding work and encourages further efforts. The Fields medal is perhaps best known and is often called the Nobel prize in mathematics. World Scientific has published a book of the Fields medallists' lectures.

Then there is the Wolf prize. The Wolf foundation describes the prize as follows: "The WOLF FOUNDATION began its activities in 1976, with an initial endowment fund of 10 million U.S. dollars donated in its entirety by the Wolf family. The main founders were Dr. Riccardo Subirana Lobo Wolf and his wife Francisca ... . Since 1978 five or six annual prizes are awarded to outstanding scientists and artists, irrespective of nationality, race, colour, religion, sex or political view, for achievements in the interest of mankind and friendly relations among people. In Science, the fields are: AGRICULTURE; CHEMISTRY; MATHEMATICS; MEDICINE; PHYSICS, and in ARTS, the prize rotates annually among Music, Painting, Sculpture and Architecture .... The official presentation of the prizes takes place at the Knesset building (Israel's parliament) and the winners are handed their awards by the President of the State of Israel at a special ceremony ...."

The Fields medal goes to young people, and indeed many mathematicians do their best work in the early years of their life. The Wolf prize often honours the achievements of a whole life. But it may also honour the work of young people.

The first Wolf prize winners in mathematics were Izrail M. Gelfand and Carl L. Siegel (1978). Siegel was born in 1896 and Gelfand in 1913. Gelfand is still active at Rutgers University. Several prize winners were born before 1910. Thus the achievements of the prize winners cover much of the twentieth century.

The documents collected in these two volumes characterize the Wolf prize winners in a form not available up to now: bibliographies and curricula vitae, autobiographical accounts, early papers or especially important papers, lectures and speeches, for example at International Congresses, as well as reports on the work of the prize winners by others. Since the work of the Wolf laureates covers a wide spectrum, a large part of contemporary mathematics comes to life in these books.

Mathematical prize winners are usually quite modest. They know that the selection committee had to choose from a large list of excellent candidates and that not only merit is needed to receive a prize, but also much luck. Quite different sets of mathematicians could illustrate with their work just as well the development of mathematics in the period covered by the Wolf prizes. 
The volumes are also a symbol of thanks to the donors who made the Wolf foundation possible and to all who worked, and work, for the success of the foundation. The editors also thank all mathematicians who prepared the material for deceased Wolf prize winners. Without their generous help the two volumes would be very incomplete.

The editors want to express their thanks to World Scientific for a splendid cooperation. They especially profited from the work and valuable advice of Dr. Sen $\mathrm{Hu}$ of World Scientific office in the USA and thank him most cordially.

S. S. Chern

F. Hirzebruch 


\section{Contents}

List of Wolf Prize winners

Preface

Lars V. Ahlfors (prepared by F. W. Gehring)

Curriculum Vitae

Publications

Ahlfors' Preface to his Collected Papers

Carathéodory's Report on Ahlfors' Work for the Fields Medal at the ICM in Oslo 1936

Ahlfors' Address as Honorary President at the Opening of the ICM in Berkeley 1986

An Extension of Schwarz's Lemma $\quad 15$

Quasiconformal Reflections $\quad 21$

Finitely Generated Kleinian Groups $\quad 32$

\section{Henri Cartan}

$\begin{array}{ll}\text { Curriculum Vitae } & 49\end{array}$

Brève analyse des travaux

Les Séminaires Cartan (allocution prononcée par J.-P. Serre en 1975) 62

Variétés analytiques complexes et cohomologie

Espaces fibrés et groupes d'homotopie. I. Constructions générales (with J.-P. Serre)

Espaces fibrés et groupes d'homotopie. II. Applications (with J.-P. Serre)

Discours prononcé le ler février 1977 à l'occasion de la remise de la Médaille d'Or du C.N.R.S.

\section{Lennart A. E. Carleson}

$\begin{array}{ll}\text { Curriculum Vitae } & 91\end{array}$

Bibliography $\quad 92$

Lennart Carleson's Work in Analysis (by P. W. Jones) 96

Lennart Carleson's Work in Statistical Mechanics and Dynamical $\begin{array}{ll}\text { Systems (by M. Benedicks) } & 108\end{array}$

On Convergence and Growth of Partial Sums of Fourier Series 120

\section{Shiing-Shen Chern}

Curriculum Vitae $\quad 143$

Bibliography $\quad 145$

My Mathematical Education $\quad 154$

S. S. Chern as Geometer and Friend (by A. Weil) 169

Abzählungen für Gewebe $\quad 173$

A Simple Intrinsic Proof of the Gauss-Bonnet Formula for

Closed Riemannian Manifolds 
Ennio De Giorgi (prepared by M. Miranda)

Ennio de Giorgi (1928-1996) (by J.-L. Lions and F. Murat) 192

Bibliography

De Giorgi's Summer Holidays and XIX Hilbert Problem

(by M. Miranda)

206

Alcune applicazioni al Calcolo delle variazioni di una teoria

della misura $K$-dimensionale

207

Minimal Cones and the Bernstein Problem (with E. Bombieri and E. Giusti)

208

New Problems in $\Gamma$-convergence and $G$-convergence

234

Samuel Eilenberg (prepared by W. S. Massey)

Samuel Eilenberg (1913-1998) (by H. Bass, H. Cartan, P. Freyd,

A. Heller and S. MacLane)

242

Bibliography

251

Natural Isomorphisms in Group Theory (with S. MacLane)

256

Singular Homology Theory

263

Axiomatic Approach to Homology Theory (with N. E. Steenrod)

288

Paul Erdös (prepared by B. Bollobás)

The Life and Work of Paul Erdös (by B. Bollobás)

292

Selected Publications of Paul Erdös

The Gaussian Law of Errors in the Theory of Additive Number Theoretic Functions (with M. Kac)

The Product of Consecutive Integers is Never a Power

(with J. L. Selfridge)

Friedrich Hirzebruch

Preliminary Remarks

Bibliography after 1987

Curriculum vitae mathematicae (by H. Grauert, G. Harder and R. Remmert)

Friedrich Hirzebruch - An Appreciation (by M. F. Atiyah)

On Steenrod's Reduced Powers, The Index of Inertia, and the Todd Genus

Arithmetic Genera and the Theorem of Riemann-Roch for Algebraic Varieties

Riemann-Roch Theorems for Differentiable Manifolds

(with M. F. Atiyah)

Learning Complex Analysis in Münster-Paris, Zürich and

Princeton from 1945 to 1953

Kunihiko Kodaira: Mathematician, Friend, and Teacher 


\section{Lars Hörmander}

Curriculum Vitae $\quad 393$

Bibliography $\quad 395$

My Mathematical Education $\quad 404$

On the Theory of General Partial Differential Operators 410

Differential Equations without Solutions $\quad 500$

Hypoelliptic Second Order Differential Equations $\quad 505$

\section{Kiyosi Itô}

Vita

Foreword in Kiyosi Itô: Selected Papers 531

Bibliography $\quad \mathbf{5 3 6}$

On a Formula Concerning Stochastic Differentials $\quad \mathbf{5 4 0}$

Multiple Wiener Integral 551

The Brownian Motion and Tensor Fields on Riemannian Manifold 564

Stochastic Differentials $\quad 568$

Joseph B. Keller

Curriculum Vitae $\quad 576$

Biographical Sketch $\quad 578$

Publication List $\quad 579$

Geometrical Theory of Diffraction $\quad 599$

Corrected Bohr-Sommerfeld Quantum Conditions for

Nonseparable Systems

Kunihiko Kodaira (prepared by Y. Miyaoka and K. Ueno)

Life of Kunihiko Kodaira (by Y. Miyaoka and K. Ueno) 623

Bibliography $\quad 647$

On a Differential-Geometric Method in the Theory of Analytic Stacks 653

On Compact Analytic Surfaces $\quad 659$

\section{Robert Langlands}

Bibliography $\quad \mathbf{6 7 4}$

$\begin{array}{ll}\text { Problems in the Theory of Automorphic Forms } & 679\end{array}$

Jean Leray (prepared by P. Malliavin)

$\begin{array}{ll}\text { Jean Leray Works (by P. Malliavin) } & 706\end{array}$

$\begin{array}{ll}\text { Biographie de Jean Leray (by P. Malliavin) } & 709\end{array}$

Sur le mouvement d'un fluide visqueux emplissant l'espace

(introduction only)

Topologie et équations fonctionnelles (with J. Schauder) 715

Sur un problème de représentation conforme posé par la théorie

$\begin{array}{ll}\text { de Helmholtz (with A. Weinstein) } & 718\end{array}$

$\begin{array}{ll}\text { L'anneau d'homologie d'une représentation } & 721\end{array}$

$\begin{array}{ll}\text { Structure de l'anneau d'homologie d'une représentation } & 724\end{array}$ 
Propriétés de l'anneau d'homologie de la projection d'un espace fibré sur sa base

Détermination, dans les cas non exceptionnels, de l'anneau de cohomologie de l'espace homogène quotient d'un groupe de Lie compact par un sous-groupe de même rang

Prolongement de la transformation de Laplace

La théorie des résidus sur une variété analytique complexe

La calcul différentiel et intégral sur une variété analytique complexe

Système d'équations aux dérivées partielles à caractéristiques multiples: probléme de Cauchy ramifié; hyperbolicité partielle (introduction only) (with Y. Hamada and C. Wagschal)

Prolongements analytiques de la solution du problème de Cauchy linéaire (with Y. Hamada and A. Takeuchi) (introduction only) 